\title{
仮想環境と実環境の重ね合わせの一手法
}

\author{
大山英 明*1 常 本 直 貴*1 舘 暲*2 井上康之*3
}

\section{A Method for Superimposing Virtual Environment and Real Environment}

\author{
Eimei Oyama ${ }^{* 1}$, Naoki Tunemoto*1, Susumu Tachi*2 and Yasuyuki Inoue $^{* 3}$
}

\begin{abstract}
Tele-existence is an advanced type of teleoperation system that enables a human operator to perform remote manipulation tasks dexterously with the feeling that he or she exists in the remote anthropomorphic robot in the remote environment. In order to extend the function of a human, an extended tele-existence system with virtual reality technology was proposed. For example, when visual information cannot be used because of smoke due to fire, then a human operator still can see the virtual environment of the scene and can control the robot. The model of the environment can be constructed from the design data of the environment. Usually, there are errors in the model of the environment. Large errors in parameters may fail operations using the virtual environment. In order to compensate for the errors, the calibration technique using model based image measurement is proposed for matching the real image and the virtual image. After the calibration, an experimental operation in the almost invisible environment was successfully conducted.
\end{abstract}

Key Words: Virtual Reality, Tele-Existence, Virtual Environment, Poor Visibility Environment, Superimpose

1. はじめに

テレイグジスタンスは, 人間があたかもロボットになったか の様な臨場感をもって，遠隔地のロボットを操作することによ り，ロボットに人間のような高度で柔軟な作業を行わせること を目指している[1][2][3].

著者らは, 人間の柔軟な問題解決能力を遠隔地のロボットに 実現するばかりでなく，ロボットの持つセンサーや計算機の助 けを借りて，仮想環境 [4]を構成し，人間の機能の拡張を行う ことを提案している 5$][6]$. 例えば，煙の中で作業を行う場 合に，人間には見ることのできない環境情報をコンピュータグ ラフィクスによって生成し，人間がその仮想環境中で作業を行 うようにすれば，煙の中で目が見えるかのごとく，ロボットを 操ることが可能になる.

この仮想環境を組み込んだ拡張テレイグジスタンスによる人 間機能の拡張の効果を実証するため, テレイグジスタンス実験

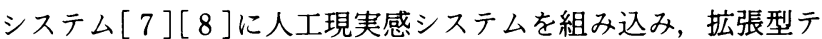
レイグジスタンスシステムを構成した $[9]$. このシステムを用

原稿受付 1992 年 12 月 28 日

*1機械技術研究所

*2東京大学先端科学技術研究センター

*3安川電機製作所株式会社

*'Mechanical Engineering Laboratory

*2RCAST, University of Tokyo

${ }^{*}$ Yasukawa Electric Corporation
いて臨場感の高い不可視情報の提示を行うことにより，不可視 環境下で作業を実行するためには，不可視情報を提示する仮想 環境と実環境の整合性を保つ必要がある。特に接触作業の実行 は，両者が十分に一致していなければ困難である.

本稿では，拡張型テレイグジスタンスシステムの仮想環境を 構成する環境モデルのパラメー夕誤差修正法を示す [10][11]. さらに，環境モデル修正の後，煙による不可視環境下におい て，レバーを回す作業実験を行い，仮想環境を用いて不可視情 報の提示を行うことにより，不可視環境下での作業が可能とな ることを示す.

\section{2. 不可視情報提示のための拡張型テレイグジスタンス}

著者らは，仮想環境 [4]をテレイグジスタンスシステムに組 み込み，人間の機能の拡張を行うことを提案している [5][6]. 仮想環境の利用により，作業訓練，不可視情報提示，予測環境 の利用による時間遅れの克服等が期待できる.

不可視情報提示による不可視環境下での作業は，仮想環境の 有効な利用法の 1 つである，例えば，工場における事故現場や 火災現場においては，煙等によって視覚情報を得ることが難し くなり，オペレータの作業能力を十分発揮できなくなる．この ような場合，作業現場の環境モデルによって仮想環境を構成 し，ロボットの視覚センサからは得ることのできない不可視情 報をオペレータに提示する．仮想環境中で作業を行うオペレー 夕の動作に従ってスレーブロボットを動かすことを考える. 仮 


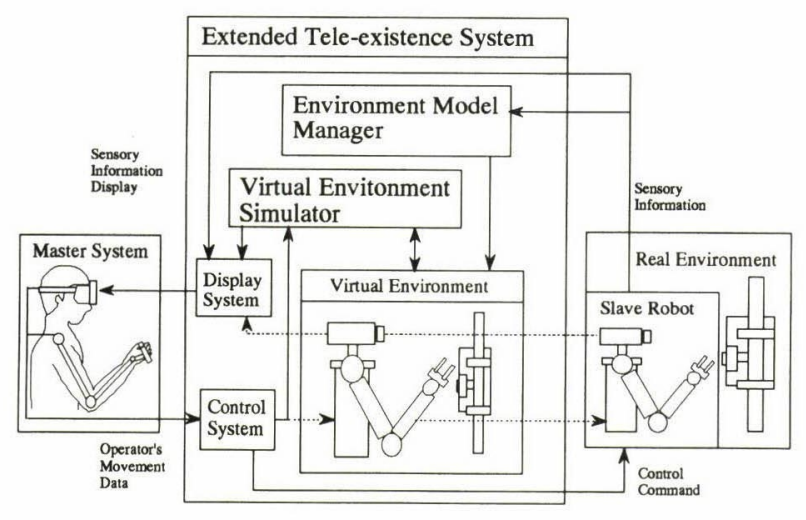

Fig. 1 Extended tele-existence system with virtual reality

想環境が実環境を十分良く近似しているならば, オペレー夕は 煙の中で目が見えるかのごとく、、ボットを操ることができ ろ.

仮想環境を組み込んだ拡張型テレイグジスタンスシステムの 概念図を Fig. 1 亿示す. 拡張型テレイグジスタンスシステム は仮想環境シミュレータと環境モデルマネージャーを持つ. 仮 想環境シミュレータは, オペレータの動作と物理法則から, 仮 想環境を更新する. 環境モデルマネージャーは, スレーブロボ ットからのセンサ情報を統合して, 仮想環境を実環境に近づけ る. 拡張型テレイグジスタンスシステムでは, オペレータは仮 想環境中に存在する仮想ロボットに接続される。仮想環境シミ ユレータと環境モデルマネージャーにより，仮想環境は実環境 を近似しており,オペレー夕は実環境中のスレーブロボットに 間接的に接続される。仮想環境の近似精度が高ければ，オペレ ータは実環境中で作業を行っているかのような現実感で, 仮想 環境において作業を行うことが可能であり，同時にスレーブロ ボットを操作することが可能である.

ロボットの作業場には, 工場内のように, 設計デー夕から環 境モデルの作成を比較的容易に行うことができる場所も多い.

このような場所では設計データを基にした環境モデルの作成が 可能である. しかしながら，一般に環境モデルは完全ではな く, 環境中に存在する物体の形状や位置, 姿勢等には誤差が存 在する。そのため実環境における物体と仮想環境における物 体, あるいは実環境に扔けるスレーブアームと仮想環境におけ るスレーブアームには, ずれが生じる. 実環境からの視覚情報 を利用する場合, 物体やアームのずれは, 操緃者の視覚フィー ドバックによって補正されるため, スレーブアームの操䋛に慣 れるまでの時間が余分にかかることを除けば，ほとんど問題と はならないが, 仮想環境の情報のみを用いて作業を行う場合, このようなずれは，作業に大きな影響を与える，見えない部分 を仮想環境によって可視化して作業を行うためには, 仮想環境 と実環境とを可能な限り近づけ, 整合性を保つことが不可欠で ある、そのため環境モデルマネージャーは, 常時, スレーブロ ボットからのセンサ情報より, 環境モデルの誤差を修正し, 仮 想環境と実環境の整合性を保つ。

なお，スレーブロボットのセンサ情報により環境モデルの修 正を行っても, 実環境と仮想環境を完全に一致させることは困

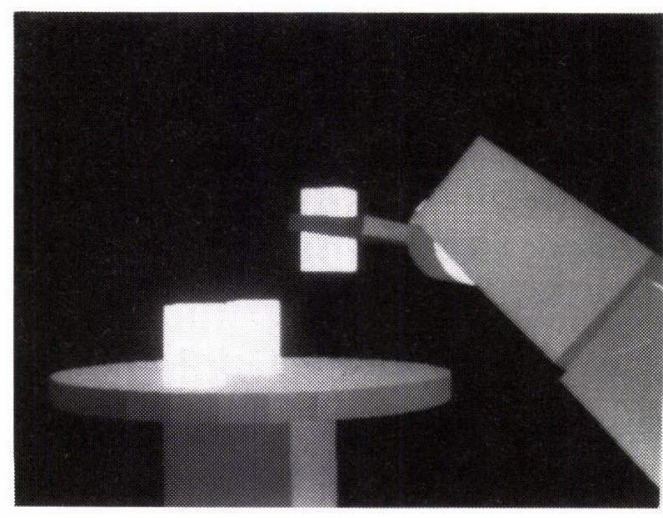

Fig. 2 Block stacking in virtual reality

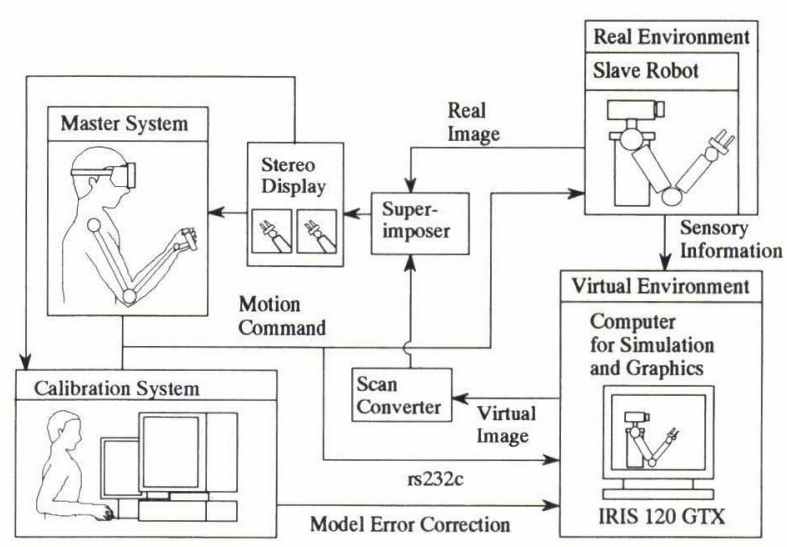

Fig. 3 System configuration of experimental extended tele-existence system

難である，スレーブロボットが，仮想環境においてオペレー夕 が行った動作をそのまま行うのでなく，オペレータの動作を基 準にしつつ, オペレータの動作の目的を達成するような自律性 がスレーブロボットに必要になる.

著者らはテレイグジスタンスによるロボット制御の有効性を 実証するために作成したテレイグジスタンス実験システム [ 7 ] [8]に, 作業訓練用の人工現実感システムを組み込み, 拡張型 テレイグジスタンス実験システムを構成した［9]．Fig. 2 に， 仮想環境中で積み木作業の訓練を行っている様子を示す，拡張 型テレイグジスタンス実験システムの具体的な構成を Fig. 3 に示す。拡張型テレイグジスタンス実験システムには，不可視 環境下での作業を行うために，画像情報を利用したキャリブレ ーションシステムを組み込んでいる[10][11]．著者らは，Fig. 1のジステムを実現することを目指して，拡張テレイグジス夕 ンス実験システムを構成したが，現時点において，実験システ ムは未完成であり，環境モデルマネージャーを実現できていな い. 環境モデルマネージャーの機能の一部をキャリブレーショ ンシステムとして実現している.このキャリブレーションシス テムは画像情報を利用しているため, 不可視環境下での作業中 に環境モデルの修正を行うことは不可能であるが，作業前のキ ャリブレーションには利用できる. 次章では, このキャリブレ 
ーションシステムの構成について具体的に述べる.

キャリブレーション後に残るモデル化誤差の問題に対して, 拡張型テレイグジスタンス実験システムでは, スレーブロボッ トの制御に，作業座標において設定した機械的インピーダンス 特性を実現するインピーダンス制御を用いて，対象物体に位置 誤差がある場合にも接触作業を可能にし，この問題を部分的に 解決している [12].

\section{3. キャリブレーションシステム}

人工現実感システムは, オペレータの視覚情報だけでなく， 触覚や力感覚の情報を提示することによって, より高度の現実 感を持った仮想環境を創出することが可能になるが, 現在の拡 張型テレイグジスタンス実験システムでは，専ら視覚情報の提 示によって，仮想環境を創出する，よって，実環境画像と仮想 環境画像とをぴったりと重祆合わせることにより，実環境と仮 想環境を重ね合わせることが可能である。

実環境と仮想環境がずれる主たる原因は，仮想環境を構成す る環境モデルにモデル化誤差があるためである．この誤差を， モデルの構造に起因するものと，モデルを構成する物体の形状 や位置, 姿勢といったパラメータの数值誤差に起因するものに 分けて考える，モデルの構造に起因する誤差とは，例えば，立 方体を四面体でモデル化してしまった場合が挙げられる。この ような場合，モデル化誤差の修正を，センサ情報から自動的に 行うことは困難である. 人間が仮想環境のモデルを再定義する ことによって, 解決を図らざるを得ない。, 一方, 環境モデルの パラメー夕誤差に起因する誤差は, 適切なパラメータの推定法 を用いることによって，自動的に修正できる，本章では，環境 モデルのパラメータ誤差を推定するキャリブレーションシステ ムの構成について述べる.

\section{1 モデルベースト画像計測システム}

筆者らは, 対象物体の画像と対象物体の形状モデルとの対応 から, 非線形最小二乗法を用いて物体の姿勢や位置といった未 知パラメータの推定を行うモデルベースト画像計測システムを 作成した[11].このシステムは，オペレータの補助によっ て，観測を行い，観測ベクトルを構成する．環境モデルはパラ メータを用いた形状モデル記述言語によって記述され，その記 述に従って, システムは観測方程式を作成し, 非線形最小二乗 法によって観測方程式を解き，自動的にパラメータの值を推定 する.このモデルベースト画像計測システムを中心とするキャ リブレーションシステムをテレイグジスタンス実験システムに 組み込み, パラメー夕誤差の推定を行い, 実画像と仮想環境画 像の重㸚合わせを行う。このキャリブレーションシステムの概 念図を Fig. 4 に示す.

特に，人工現実感システムに組み込むに当たり，モデルベー スト画像計測システムのモデリング機能を用いて, 形状モデル 記述言語で記述した環境モデルを仮想環境の描画プログラムに コンパイルして，高速な描画を可能にし，また，その描画プロ グラムをそのまま用いて, 観測方程式の観測モデルを計算し, 数值微分を用いて, 非線形最小二乗法で用いるヤコビ行列を計 算するようにした，それにより，以下のような特徵がある.

（1）環境モデルの記述に基づいて，パラメータ值の修推定

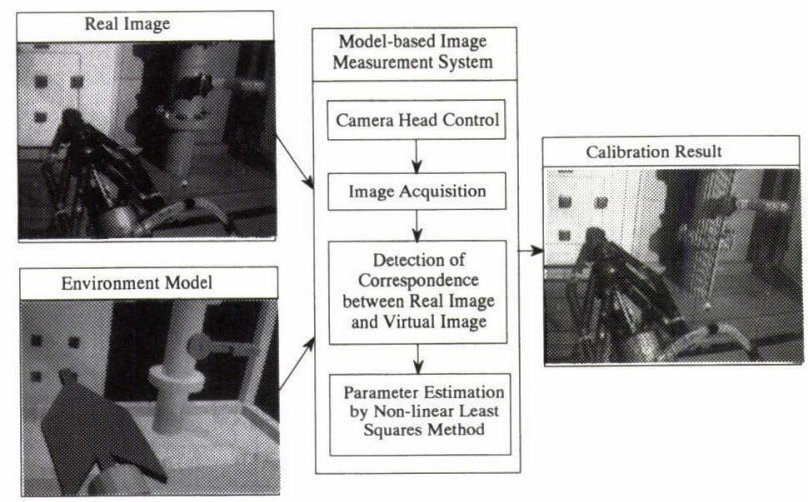

Fig. 4 Model based image measurement system

が可能である.

（2）観測方程式に可観測性があれば，任意のパラメータの 値の推定が可能である.

(3) 観測モデルを数式モデルで表すことのできる観測量だ けでなく，コンピュータプログラムで，值を計算でき る観測量であれば，コンピュータプログラムを用意す ることにより，任意の観測量を利用できる.

人工現実感システムのキャリプレーションにおいては, 環境 モデルのパラメータの修正を, 環境モデルの記述に基づいて行 う必要がある。例えば, ある回転軸の回りに回転するレバーの 想定した座標系における位置, 姿勢は, 適当なセンサと推定プ ログラムによって得ることができるが，人工現実感を創出する ためのシミュレーションに必要であるのは, レバーの回転軸回 りの回転角であり, 計測は, 最終的には, 回転角を推定するも のでなければならない。 また，人工現実感システムの環境モデ ルのパラメータには, 物体の寸法誤差, 位置誤差, 姿勢誤差 等, 色々な種類があり, 提案した手法は, 環境モデルのパラメ ー夕誤差修正に非常に適している.

現時点においては，Fig. 3 に示すように，スレーブロボット のオペレータとは別のオペレータが, キャリブレーションを行 っている. 画像を処理して, 自動的にキャリブレーションを行 うことが望ましいが，画像から自動的にパラメータを推定する には, 画像上の特徵点と物体の形状モデル上の点とを対応づけ る画像認識処理が必要となり，現時点において，十分信頼性の 高い画像認識プログラムの開発に成功しておらず，そのため, 対応付けは, オペレータの認識能力に依存している.

\section{2 末知パラメータの推定法}

画像によって観測される物体上の点の位置や線の傾き, 線の 位置等によって構成される観測べクトル $\boldsymbol{y}$ を以下のようにモ デル化する.

$$
\boldsymbol{y}=\boldsymbol{f}(\boldsymbol{p}, \boldsymbol{x})+\boldsymbol{\omega}
$$

観測量ベクトル $\boldsymbol{y}$ は, 既知のパラメータベクトル $\boldsymbol{p}$, 未知パ ラメータベクトル $\boldsymbol{x}$ によって構成される観測量のモデル $\boldsymbol{f}(\boldsymbol{p}$ $x)$ と, それに加わる観測ノイズ $\omega$ の和によってモデル化する ことができる.

観測ノイズが正規分布に従うものと仮定する．ノイズの共分 
散行列を

$$
\Sigma_{y}=E\left(\omega \omega^{T}\right)
$$

とする. $E(\boldsymbol{A})$ は行列 $\boldsymbol{A}$ の期待值である. 観測量の重み行列 を次式のように定義し,

$$
\boldsymbol{W}=\boldsymbol{\Sigma}_{y}^{-1}
$$

評価関数

$$
S=(\boldsymbol{y}-\boldsymbol{f}(\boldsymbol{p}, \boldsymbol{x}))^{T} \boldsymbol{W}(\boldsymbol{y}-\boldsymbol{f}(\boldsymbol{p}, \boldsymbol{x}))
$$

を最小化することにより，観測ノイズが正規分布に従うという 仮定が成立すれば，未知パラメータ $x$ の值の最適推定を行う ことができる，㛜密にはこの仮定は成立しない場合も多いが, その場合でも最尤推定值に近い解を得られることが多い.この ような形式の評価関数の最小化問題の解法は非線形最小二乗法 と呼ばれている.

観測モデルのヤコビ行列を $\boldsymbol{H}$ とおく，H は次式のように定 義される.

$$
\boldsymbol{H}=\partial \boldsymbol{f}(\boldsymbol{p}, \boldsymbol{x}) / \partial \boldsymbol{x}
$$

$x$ の值を多様に反映する十分な個数の観測量があれば, 真の解 の付近でヤコビ行列 $\boldsymbol{H}$ はフルランクとなり, 未知パラメータ ベクトル $\boldsymbol{x}$ の推定が可能となる.

代表的な非線形最小二乗法である Marquardt 法[13]の反復 改良演算は

$$
\begin{aligned}
\boldsymbol{x}_{n+1} & =\boldsymbol{x}_{n} \\
& +\left(\boldsymbol{H}^{T} \boldsymbol{W} \boldsymbol{H}+\lambda \boldsymbol{I}\right)^{-1} \boldsymbol{H}^{T} \boldsymbol{W}\left(\boldsymbol{y}-\boldsymbol{f}\left(\boldsymbol{x}_{n}\right)\right)
\end{aligned}
$$

のように $\boldsymbol{x}$ の值を反復改良する。 $\lambda$ は非線形性の度合いに応 じて調節するスカラーパラメータである. 収束の終盤において は，システムは通常線形に近くなり，その場合 $\lambda$ は減少傾向

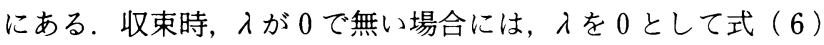
を計算する， $\boldsymbol{H}^{T} \boldsymbol{W} \boldsymbol{H}$ の逆行列が計算できない場合には, $\boldsymbol{H}$ がフルランクでなく，この観測方程式による $\boldsymbol{x}$ の推定は不可 能とみなせる.

\section{3 画像の観測モデル}

仮想環境画像と実画像との重ね合わせを行う場合において, 重要なことは, 色や光沢, 明暗といった画素の性質ではなく, 画像を構成する点や線が重なることである，よって，本システ ムでは，画像を構成する点の位置や直線の傾き，切片等を観測 量として観測方程式を定義する，本節では，最も単純な画面上 の点の位置の観測モデルについて述べる.

物体上の点の画面上の位置の観測モデルを定義するために, 3 次元ベクトル

$\boldsymbol{X}=(x, y, z)^{T}$

を用いて，以下のように代表的な変換をべクトル関数として定 義する.

$$
\text { (a) } \begin{aligned}
\quad \text { スケーリング変換 } \\
\quad \\
\quad \boldsymbol{s c a l e}(\boldsymbol{s}, \boldsymbol{X})=\left(s_{x} x, s_{y} y, s_{z} z\right)^{T} \\
\boldsymbol{s}=\left(s_{x}, s_{y}, s_{z}\right)^{T}: \text { スケーリングベクトル }
\end{aligned}
$$

(b) 並進変換

$$
\operatorname{trans}\left(X_{p}, X\right)=X+X_{p}
$$

$$
\boldsymbol{X}_{p}=\left(x_{p}, y_{p}, z_{p}\right)^{T}: \text { 並進を定義する } 3 \text { 次元ベクトル }
$$

(c) 回転変換

$$
\text { rotate }(\Theta, X)=C(\Theta) X
$$

$$
\boldsymbol{\Theta}=(\phi \theta, \psi)^{T} \text { : 回転を定義するオイラー角ベクトル }
$$

$\boldsymbol{C}(\boldsymbol{\Theta}): 3$ 行 3 列の回転変換行列 (オイラー角の三角関 数の積和によって表される.)

さらに，並進並びに回転変換において逆変換を考える.

( b )' 逆並進変換

$$
\begin{gathered}
\operatorname{trans}^{-1}\left(X_{p}, X\right) \\
=\operatorname{trans}\left(-X_{p}, X\right) \\
\operatorname{rotate}^{-1}(\Theta, X) \\
=C(\Theta)^{T} X
\end{gathered}
$$

(c )' 逆回転変換

物体上の点の 3 次元の位置ベクトルは, 適当な基本ベクトル に, スケーリング変換, 回転変換, 並進変換を施せば, 得るこ とができる. 可動部分を持つ物体については，可動部を適当な 変換に対応付け, 適当なパラメー夕を導入することによって, 定義できる，一般的な物体上の点 $\mathrm{k}$ の 3 次元位置 $\boldsymbol{X}_{3 d}^{(k)}$ は, 適 当な基本べクトル $\left(\right.$ 例えば, $\left.\boldsymbol{b}=(1,1,1)^{T}\right)$ に，スケーリング変 換を施し,さらに， $m$ 回の並進変換，並びに $n$ 回の回転変換 を適当な順序で施すことによって, 次のように得ることができ る。

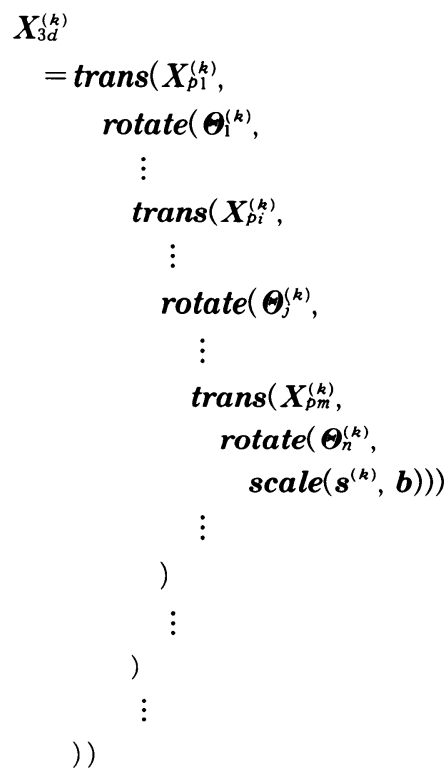

$\boldsymbol{s}^{(\boldsymbol{k})}, \boldsymbol{X}_{p i}^{(k)}(0 \leqq i \leqq m), \boldsymbol{\Theta}_{j}^{(k)}(0 \leqq j \leqq n)$ は，それぞれ，スケーリ ングベクトル，並進ベクトル，オイラー角ベクトルである.

仮想環境の基準となる世界座標系上における物体上の点 $k$ の位置 $\boldsymbol{X}_{w}^{(k)}$ は, 物体の位置が $\boldsymbol{X}_{p}^{(k)}$, その姿勢がオイラー角べ クトル $\boldsymbol{\Theta}^{(k)}$ で表されるとすると,

$$
\begin{aligned}
& X_{w}^{(k)}=\operatorname{trans}\left(X_{p}^{(k)},\right. \\
& \left.\operatorname{rotate}\left(\Theta^{(k)}, X_{3 d}^{(k)}\right)\right)
\end{aligned}
$$

のように得ることができる. さらに, 世界座標系とカメラ座標 系の関係が,

$$
\begin{aligned}
\boldsymbol{X}_{3 d}= & \boldsymbol{C}\left(\boldsymbol{\Theta}_{c}\right) \boldsymbol{X}_{c}+\boldsymbol{X}_{p c} \\
= & \operatorname{trans}\left(\boldsymbol{X}_{p c},\right. \\
& \left.\quad \text { rotate }\left(\boldsymbol{\Theta}_{c}, \boldsymbol{X}_{c}\right)\right)
\end{aligned}
$$

であるとすると, 次式を得る.

$$
\boldsymbol{X}_{c}^{(k)}=\left(x_{c}^{(k)}, y_{c}^{(k)}, z_{c}^{(k)}\right)
$$




$$
\begin{aligned}
= & C\left(\boldsymbol{\theta}_{c}\right)^{-1}\left(X_{w}^{(k)}-X_{p c}\right) \\
= & \operatorname{rotate}^{-1}\left(\Theta_{c},\right. \\
& \left.\quad \operatorname{trans}^{-1}\left(X_{p c}, X_{w}^{(k)}\right)\right)
\end{aligned}
$$

カメラ座標系の $z$ 軸が, カメラの視線方向と一致してお り, 画面座標系の $x$ 軸が, カメラ座標系の $x$ 軸に, 画面座標 系の $y$ 軸が, カメラ座標系の $y$ 軸にそれぞれ一致しているもの とすれば，カメラ座標系の $z=K$ に存在する画面座標系上への 透視変換は次のように定義できる。

(d) 透視変換

$$
\begin{gathered}
\operatorname{perspec}(\boldsymbol{X})=\left(x_{i}, y_{i}\right)^{T} \\
=(K x / z, K y / z)
\end{gathered}
$$

実画面上で観測した点 $k$ の位置 $\boldsymbol{X}_{i R}^{(k)}=\left(x_{i R}^{(k)}, y_{i R}^{(k)}\right)^{T}$ を観測量 とすると, 点 $\mathrm{k}$ の画面上の位置の観測モデル $\boldsymbol{X}_{i v}^{(k)}$ は, 式 (16) で定義される $\boldsymbol{X}_{c}^{(k)}$ を用いて，以下のように定義できる.

$$
\boldsymbol{X}_{i V}^{(\boldsymbol{k})}=\left(x_{i V}^{(\boldsymbol{k})}, y_{i v}^{(k)}\right)^{T}
$$

$$
=\operatorname{perspec}\left(X_{c}^{(k)}\right)
$$

$v$ 個の実画面上の点について，観測を行うこととすれば， $2 v$ 個の要素を持つ観測ベクトル $y$ を以下のように定義できる.

$$
y=\left(\boldsymbol{X}_{i R}^{(1) T}, \cdots, \boldsymbol{X}_{i R}^{(\nu) T}\right)^{T}
$$

これに対応する観測モデルは式（18）で定義される $\boldsymbol{X}_{i v}^{(k)}$ を用 いて，以下のように定義できる.

$$
\boldsymbol{f}(\boldsymbol{p}, \boldsymbol{x})=\left(\boldsymbol{X}_{i V}^{(1) T}, \cdots, \boldsymbol{X}_{i V}^{(v) T}\right)^{T}
$$

これまでに用いられたパラメータをまとめて，以下のような 点 $k$ に関するパラメータベクトルを作る.

$$
\begin{aligned}
\boldsymbol{P}^{(k)}= & \left(\boldsymbol{s}^{(k) T}, \boldsymbol{X}_{p 1}^{(k) T}, \cdots, \boldsymbol{X}_{p m}^{(k) T}, \boldsymbol{\Theta}_{1}^{(k) T}, \cdots, \boldsymbol{\Theta}_{n}^{(k) T},\right. \\
& \left.\boldsymbol{X}_{p}^{(k) T}, \boldsymbol{\Theta}^{(k) T}\right)^{T}
\end{aligned}
$$

さらに，観測した $v$ 個の点について，パラメータベクトルを まとめて，最終的に以下のようなパラメータベクトルを作る.

$$
\boldsymbol{P}=\left(\boldsymbol{x}_{p c}^{T}, \boldsymbol{\Theta}_{c}^{T}, \boldsymbol{P}^{(1) T}, \cdots, \boldsymbol{P}^{(v) T}\right)^{T}
$$

$\boldsymbol{P}$ の要素のうち, 推定したいパラメータをまとめて, 未知パ ラメータベクトル $\boldsymbol{x}$ とし, 残りを既知パラメータベクトル $\boldsymbol{p}$ とする. 逆に $\boldsymbol{x}$ と $\boldsymbol{p}$ から $\boldsymbol{P}$ を構成するべクトル関数を $\operatorname{param}(\boldsymbol{p}, \boldsymbol{x})$ とすれば,

$$
\boldsymbol{P}=\operatorname{param}(\boldsymbol{p}, \boldsymbol{x})
$$

として, パラメータの値を設定し, 式(13) (14)(16)(18)(20)の 定義を用いて，観測モデル $\boldsymbol{f}(\boldsymbol{p}, \boldsymbol{x})$ の值を計算できる.

3.4 インプリメンテーション

本節では，キャリブレーションシステムの各処理が，具体的 にどのように実現されているか述べる.

キャリブレーションシステムはスレーブロボットに指令を送 って適切な位置, 姿勢をとらせ, スレーブロボットに登載され ているビデオカメラからの画像を取り込む. 次に, オペレータ の指示に従って, カメラからの実画像と仮想環境画像との間で 対応付けを行い，画像の観測方程式を構成する. 画像上の点の 位置の取得においては，拡張テイレイグジスタンスシステムの 画像提示システムの特徵を有効に利用している. Fig. 3 に示す ように拡張テレイグジスタンス実験システムの画像提示システ ムは, スレーブロボットからの実画像とコンピュータによって 生成した仮想環境画像の両方をスーパーインポーザーによって 切り替えて表示でき，また，実画像とコンピュータグラフィク スを重ねて同時に表示することができる.コンピュータグラフ
イクスの RGB 各色の明るさを 0 から 1 で表すものとすると， スーパーインポーザーは，コンピュータグラフィクスで生成し た画像において $(\mathrm{R}, \mathrm{G}, \mathrm{B})=(0,0,1)$ となる画素では実画像 を表示しそれ以外の画素では仮想環境画像をそのまま表示する よう設定している. 実画像を表示するためにグラフィクス画面 を青色にしたとき，マウスカーソルの色を青以外の色にしてい れば，マウスカーソルと実画像を同時に表示でき，マウスの位 置情報を得ることにより，実画像上の点の位置 $\boldsymbol{X}_{i}$ を計測でき る. また， 2 点を指定することにより，画面上の直線を指定で きる.

観測方程式を構成する際において，画面上の点と形状モデル 上の点とが同一のものでなければならない. 画面上に見える 1 点を, 計算機内の形状モデル上の点に対応付ける問題は画像認 識問題である. 現時点では画像認識技術は信頼性が低いため, 自動的な対応付けは困難であり，人間が画面上の点に対応する 仮想環境画像の物体上の点をマウスで指示することによって,

対応付けを行う. 実画像上の点に対応する仮想環境画像上の点 をマウスで指示したとき, マウスカーソル位置にもっとも近い モデル上の頂点が選択され, 実画像と環境モデルとの間で対応 付けが行われる.

対応付けによって得られた観測方程式を解いて，パラメータ 誤差を推定する非線形最小二乗法においては, Marquardt 法 を利用した. 観測モデル $\boldsymbol{f}(\boldsymbol{p}, \boldsymbol{x})$ の值を計算し, さらに, 数值 微分によってそのヤコビ行列 $\boldsymbol{H}$ を計算し, 未知パラメータ $\boldsymbol{x}$ の值の推定を行う. 画面上における点の位置の観測モデルは, 前節で述べたように, 基本べクトルに, 種々の変換を施すこと によって, 得ることができるが, この変換処理は, 人工現実感 システムの描画プログラムと同じである. 本システムでは式 (20)を計算するために，仮想環境の描画プログラムをそのまま 利用している。 そのために, 前節のパラメータ值設定関数 $\boldsymbol{p a r a m}(\boldsymbol{p} \boldsymbol{x})$ を作成し, 仮想環境の描画プログラムの物体の位 置や姿勢などのパラメータの值を, 外部から変えることができ るようにした。 未知パラメータ $\boldsymbol{x}$ の值を設定し, 描画プログ ラムを動作させれば，画面上の点の位置を得ることができる. ヤコビ行列 $\boldsymbol{H}$ は, $d$ を適度に小さな実数として, ベクトル $\boldsymbol{d}^{(j)}$ を定義し, 以下のような数值微分によって, 計算してい る.

$$
\begin{gathered}
H_{i j}=\left(f_{i}\left(\boldsymbol{p}, \boldsymbol{x}+\boldsymbol{d}^{(j)}\right)-f_{i}(\boldsymbol{p}, \boldsymbol{x})\right) / d \\
d_{i}^{(j)}= \begin{cases}d & (i=j) \\
0 & (i \neq j)\end{cases}
\end{gathered}
$$

さらに，対話的に計測を行うためにヒューマンインターフェ イスを作成し，カメラを登載しているスレーブロボットの位 置, 姿勢, 画像で計測を行う対象物体, 推定するパラメー夕等 をマウスを用いて，対話的に指定できるようにしている.

\section{5 推定の手順}

本節では，モデルベースト画像計測における未知パラメータ 推定のために, オペレータが行う操作手順を示す. 現在の操作 手順は以下の通りである.

（1）計測対象が画面上に来るようににカメラヘッドに指令 値を送る。

（2）画面を実画像表示し，画面上の頂点位置をマウスで指 


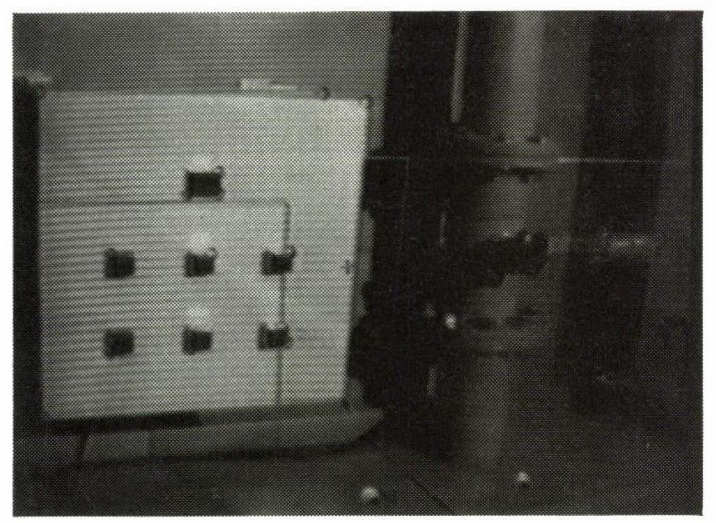

(a) Camera image

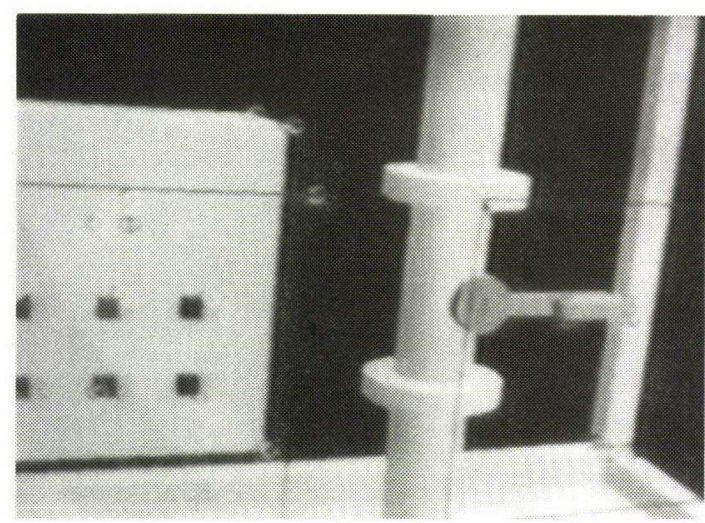

(b) Virtual image

Fig.5 Real image and virtual image during correspondance detection

示することによって，画面上の頂点の位置を計測する (Fig. 5 (a) 参照).

（3）画面を仮想環境画像に切り替え，実画像上の点に対応 する点をマウスで指示する (Fig. 5 (b ) 参照).

（4）十分な数の観測量が得られるまで，（1)から（３）の手 順を繰り返す.（2）と（３）の順序は逆にしてもよい.

（5）推定すべきパラメータを選択する.

（6）十分な数の観測量が得られた後，推定アルゴリズムに よって，未知パラメー夕の值を推定する．複数の初期 值より推定を行い. 最も残差の小さいものを選ぶ.十 分な推定が行えなかった場合には（1）から（3)を繰り 返して, 十分な観測量を得る.

Fig. 5 (a) に実画像と仮想環境画像を対応付けている際の実 画像を示す. Fig. 5 (b) に，仮想環境画像を示す。画像中の物 体の頂点に付いている円は，実画像と仮想環境画像との間で対 応付けを行った点を示している. 十分な個数の対応付けが完了 した後, 非線形最小二乗法により推定を行う.

\section{4. キャリブレーション実験}

画像情報を用いて, パラメー夕誤差を推定し，実画像と仮想 環境を重ね合わせるキャリブレーションの実験を行った.

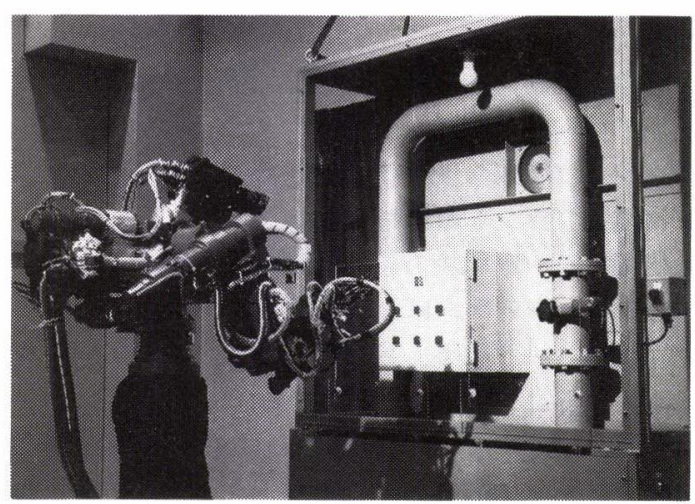

Fig. 6 Tele-existence experimental environment

\section{1 模擬プラント環境}

著者らはテレイグジスタンスによるロボット制御の有効性を 検証するためのテレイグジスタンス実験環境として，模擬プラ ント環境を作成した $[9]$.この環境は，工場内の部屋を想定 し，パイプやレバー等によって構成されている. Fig. 6 にその 外観を示す。この実験環境は，スモークマシンによって，煙を 発生させることができ, 写真の右の方に見えるレバーを回すと 煙が止まるようになっている，また左の箱にあるボタンは，換 気扇のスイッチになっている.

今回の実験環境は, 単純な形状要素の組合せによって構成さ れており，計算機に形状データを入力することは比較的容易で ある、形状データはサーフェスモデルによって, 記述されてい る. Fig. 5 (b ) は環境モデルをコンピュータグラフィクスによ つて表示したものである，仮想環境においても，煙を止めるた めのレバーと, 換気扇を回すためのボタンを操作することがで きる，ボタンを押すとビープ音がなるようになっている．実験 環境の形状データが得られるため, 推定すべきパラメータは, 環境モデルの可動部のパラメータの值と環境とロボットの相対 位置誝差, 相対姿勢誤差である.

\section{2 キャリブレーションの手順}

現時点において，テレイグジスタンスシステムのスレーブロ ボットの首とアームには, 軽量化のため関節角のゼロ点がな く, 停止状態でアームを動かすと, 原点位置がずれ, 仮想ア一 ムと実アームでずれが生じてしまうという問題点があり, 首と アームの関節角オフセットも作業のために推定する必要があ る. 通常のロボットでは, ロボットの首やアームのオフセット 等は, オフライン計測で，あらかじめ測定しておけるものであ るが, 本システムでは, キャリブレーションによってオフセッ ト值を推定する.

今回のキャリブレーションにおいては, 既知パラメータは, ロボットの位置, 姿勢, 首やアームの関節角であり, 観測量 は, オペレータの画像上のアームや対象物の特徵点や特徴線の 画面上での位置であり, 推定すべきパラメータは, 模擬プラン ト環境の位置と姿勢の誤差, スレープロボットの首やアームの 関節角オフセットである.

実画像と仮想環境画像の重ね合わせのためのキャリブレーシ ヨンは, 以下のように行う. 
(1) 首のキャリブレーションを壁に張ってあるマーカーを 見て行う.

（2）スレーブロボットに指令を送って，首を動かし，視界 に模擬プラント環境を持ってくる.

(3) 模擬プラント環境の位置誤差, 姿勢誤差をキャリブレ ーションシステムにより推定する.

（4）コンピュータより, 指令を送って, 首とアームを動か し，視界にアームを持ってくる.

（5）アームにいろいろな姿勢をとらせ，画像計測によっ て，アームの間接角オフセットを推定する。反復計算 の収束時において，観測方程式のヤコビ行列がフルラ ンクで無い場合には，アームの姿勢を変え，新たな観 測值を追加する.

(1)の首のキャリブレーションは, 提案法ではなく, ロボッ トより約 $7[\mathrm{~m}]$ 離れた壁にロボットの目の高さに, 水平に張っ た 3 つのマーカーをカメラの画像中で見ながら, 首の関節角を ゆっくりと変えて, マーカーが計算通りの画像中の位置にくる よう調節することによって行った，正確な測定装置を持ってい ないため, このキャリブレーションの誤差は不明である。この 誤差は，後の測定において，モデル化していない誤差源とな る.

\section{3 キャリブレーションの諸条件}

キャリブレーション後に残る誤差の評価のために, 基準座標 系として直交座標系を模擬プラント環境を基準に設定する。模 擬プラント環境を正面に見る位置に立った場合，背中の方向に $x$ 軸，水平右手方向に $y$ 軸，垂直上方向に $z$ 軸をとり，これ を基準座標系と呼ぶことにする。なお，模擬プラント環境の位 置・姿勢には誤差があり, キャリブレーションにおいて誤差推 定を行うが, 誤差を修正した後の仮想環境中の模擬プラント環 境を基準として基準座標系を設定する.

水平に $6.5[\mathrm{~cm}]$ 離れた 2 つのカメラの画像を用いて画像計 測を行う. 画像計測に用いた画像は, 水平方向 669 画素, 垂直 方向 453 画素であり, 水平方向視野角は 40 度である. 画像の 中心部の 1 画素は, カメラの $1[\mathrm{~m}]$ 前方では $0.11[\mathrm{~cm}]$ に相当 する. 普通のオペレー夕は, 明確に点が表示されている場合に おいて, マウスによる通常のポインティングにより, 各軸方向 に対して, RMS (Root Mean Square) エラー 1.5 画素程度の ポインティング精度を持っているが, 実際の画像においては, 点の位置が明確でなくなるため精度は悪化する。

\section{4 キャリブレーション結果}

Fig. 7,8 に模擬プラント環境の位置・姿勢の計 6 自由度のパ ラメー夕誤差の推定によるキャリブレーションの結果の例を示 す. Fig. 7 は模擬プラント環境のレバー位置より, 約 $1.5[\mathrm{~m}]$ 離れた地点から計測したものであり, Fig. 8 は, 約 $0.7[\mathrm{~m}]$ 離 れた地点から計測したものである。それぞれ，(a)にパラメー 夕誤差を推定していない状態で, 実画像と仮想環境画像（ワイ ヤフレーム表示) を重ね合わせたものを示し，（b）に，特徴点 や直線の対応付けを行い, 最小二乗法によって, パラメー夕誤 差を推定して，重ね合わせた画像を示す。実画像と仮想環境画 像が完全に重なっていないのは, モデル化していない誤差源が

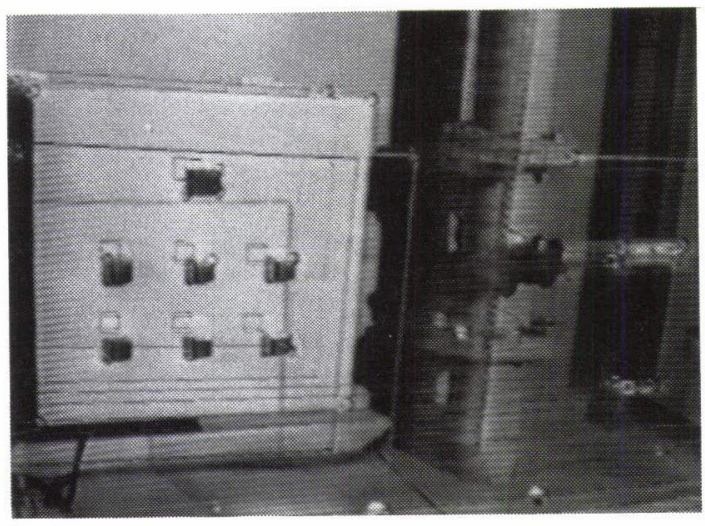

(a) Before calibration

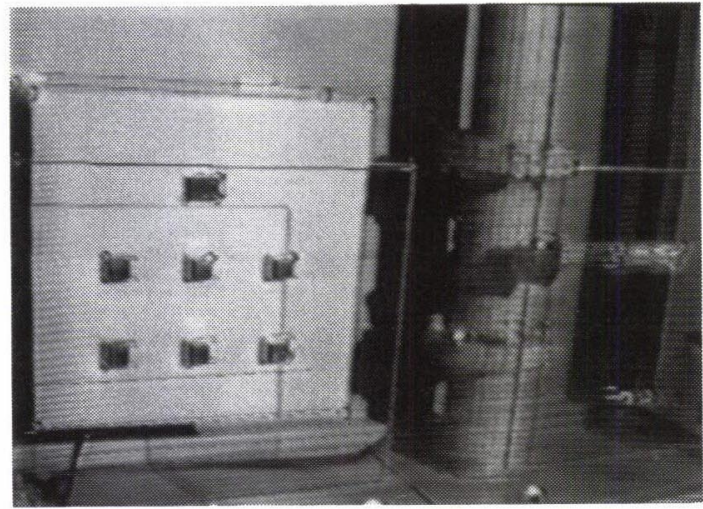

(b) After calibration

Fig. 7 Calibration of plant environment

存在しているためと考えられる

カメラが理想的に取り付けられているとすれば，観測点の画 面上での位置から，その点の 3 次元空間上における位置を推定 でき，仮想環境中での対応点との距離誤差を推定できる. Fig. 8 の場合, 計算の結果, レバーの握り手上に存在する 8 つの観 測点の位置誤差の, カメラの視線方向, 画像の水平方向, 垂直 方向の各軸方向の最大值は, 順に, $2.8[\mathrm{~cm}], 1.1[\mathrm{~cm}], 0$, $4[\mathrm{~cm}]$ であった，基準座標系では， $x$ 軸方向 $2.4[\mathrm{~cm}], y$ 軸方 向 $1.1[\mathrm{~cm}], z$ 軸方向 $1.5[\mathrm{~cm}]$ であった.

同様にして, アームの 7 つの関節角のオフセットの推定を行 つた.そのときの画像を Fig. 9 に示す. 本アームは 7 自由度 アームであり, 手先しか見えない場合には, 一度の観測では, オフセットの推定ができないが，アームにいろいろな姿勢をと らせて, 計測することによって, オフセットの推定が可能にな る. 今回は 10 通りの姿勢をとらせて, 各姿勢において約 8 点 を観測点とし，計測を行った.

計測の結果，ハンドの接触部である先端部に存在する 6 個の 観測点の, カメラの視線方向, 画像の水平方向, 垂直方向の各 軸方向の誤差の最大值は, 順に, $4.5[\mathrm{~cm}], 1.6[\mathrm{~cm}], 0.6[\mathrm{~cm}]$ であった。基準座標系での各軸の最大誤差は, ロボットがレバ 一回転作業を行うときの姿勢をとった状態を想定した場合, $\mathrm{x}$ 軸方向 $3.9[\mathrm{~cm}], y$ 軸方向 $2.2[\mathrm{~cm}], z$ 軸方向 $2.0[\mathrm{~cm}]$ であっ 


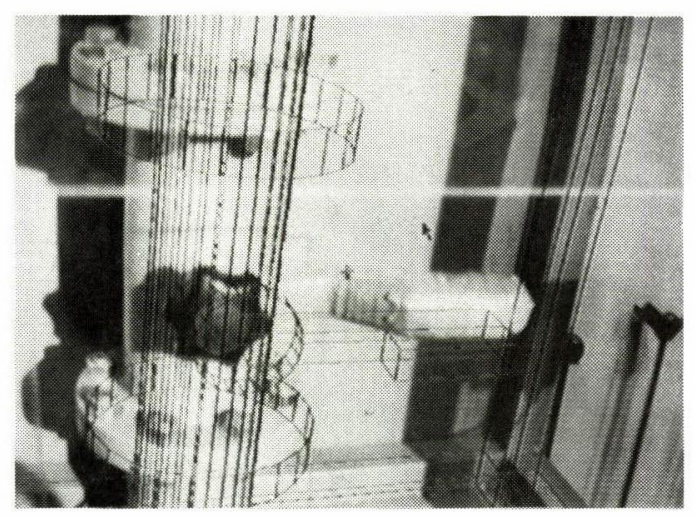

(a) Before calibration

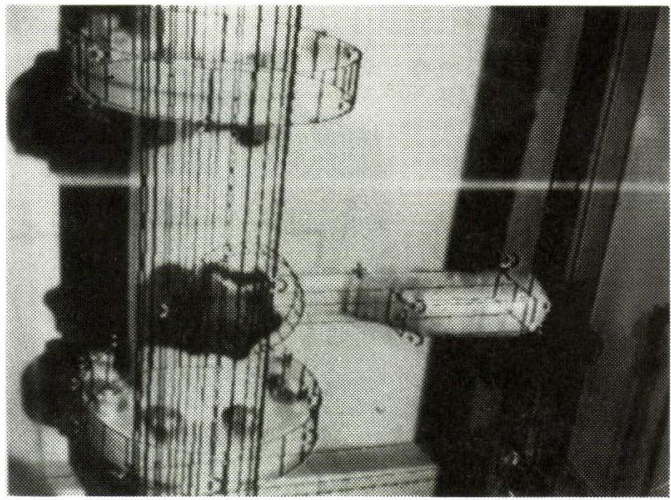

(b) After calibration

Fig. 8 Calibration of plant environment

Table 1 Calibration conditions and results

\begin{tabular}{l|c|c}
\hline $\begin{array}{l}\text { Estimated } \\
\text { Parameters }\end{array}$ & $\begin{array}{c}\text { Position and } \\
\text { Attitude of } \\
\text { Plant Environment }\end{array}$ & $\begin{array}{c}\text { Offsets of } \\
\text { Joint Angles }\end{array}$ \\
\hline Number of Images & $1 \times 2$ (Stereo) & $10 \times 2$ (Stereo) \\
\hline Number of Attitudes & 1 & 10 \\
\hline $\begin{array}{l}\text { Number of Measured } \\
\text { Points }\end{array}$ & 24 & 84 \\
\hline $\begin{array}{l}\text { Number of Estimat- } \\
\text { ed Parameters }\end{array}$ & 6 & 7 \\
\hline $\begin{array}{l}\text { RMS Error on Image } \\
\text { (Pixels) } \\
(x, y i)\end{array}$ & $8.5($ Lever $)$ & $16.5($ Hand $)$ \\
\hline $\begin{array}{l}\text { RMS Error }[\mathrm{cm}] \\
(x, y, z)\end{array}$ & $\begin{array}{c}2.0(\text { Lever }) \\
(1.6,0.7,1.0)\end{array}$ & $\begin{array}{c}3.8(\text { Hand }) \\
(3.2,1.5,1.5)\end{array}$ \\
\hline $\begin{array}{l}\text { Max. Error }[\mathrm{cm}] \\
(x, y, z)\end{array}$ & $\begin{array}{c}2.8(\text { Lever }) \\
(2.4,1.1,1.5)\end{array}$ & $\begin{array}{c}4.9(\text { Hand }) \\
(3.9,2.2,2.0)\end{array}$ \\
\hline
\end{tabular}

た. ただし，観測を行っていない姿勢では，誤差が増大した． レバー回転作業時に，実画像と仮想環境画像を重ねて表示した 画像を記録し，画面上のハンド先端の詔差を計測した。これ に, 首とアームの姿勢から計算したカメラとハンドの間の距離 情報と組み合わせて，カメラの視線に垂直な方向の位置誤差を

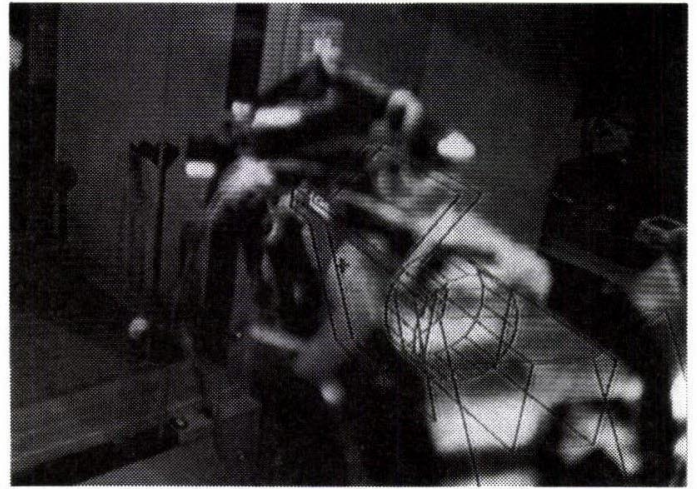

(a) Before calibration

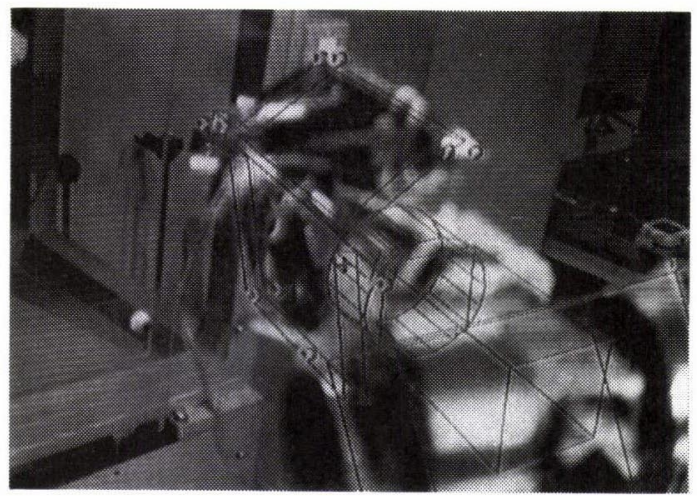

(b) After calibration

Fig. 9 Calibration of joint angles

計算した結果, $6.9[\mathrm{~cm}]$ に達する場合があった。

Fig. 8 の模擬プラント環境の位置・姿勢推定と Fig. 9 のアー ムの関節角オフセット推定の実験の条件と結果を Table 1 にま とめる. Table 1 において, 推定誤差は, 画面座標系 $\left(x_{i}, y_{i}\right)$ と基準座標系 $(x, y, z)$ で示した.

\section{5. 不可視環境下での作業実験}

実環境と仮想環境の重ね合わせが成功したことを確認するた めに，不可視情報提示による作業実験を行った。 まず，模擬プ ラント環境において, スモークマシンによって, 煙を発生さ せ，スレーブロボットからの視覚情報が利用できない状態にす る.続いて，オペレータの視覚入力を実環境から仮想環境に切 り替え，仮想環境において作業を行うことにより，不可視環境 下に存在するロボットを操った.レバー回転作業という比較的 要求精度の低い作業の遂行に成功した. 作業中のスレーブロボ ットの様子を Fig. 10 に示す.

比較のために, Fig. 11 に通常の作業中のカメラ画像に仮想 環境のワイヤフレームモデルを重ねて描いた画像を示す.

ハンドが上方からレバーに接触し，十分な力をレバーに加え さえすれば，レバーを回転させることができる，想定している レバー回転作業では，仮想環境において，ハンド先端の接触部 （想定している姿勢において，基準座標系の $\mathrm{x}$ 軸方向 $10[\mathrm{~cm}]$, $y$ 軸方向 $1.5[\mathrm{~cm}], z$ 軸方向 $10[\mathrm{~cm}]$ の大きさである.)の中心 


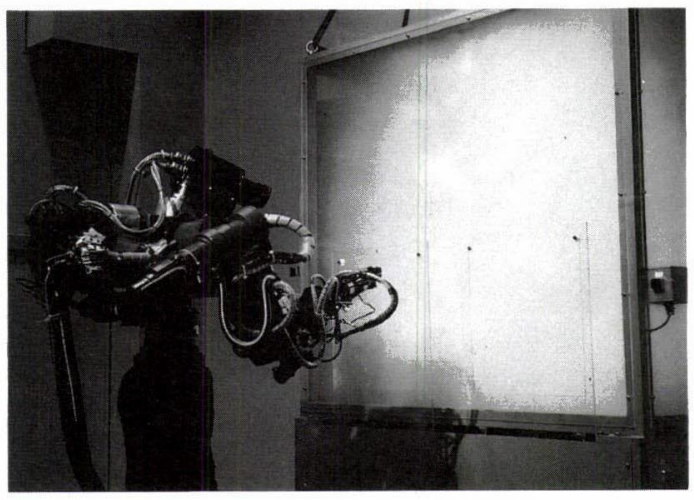

Fig. 10 Operation in almost invisible environment

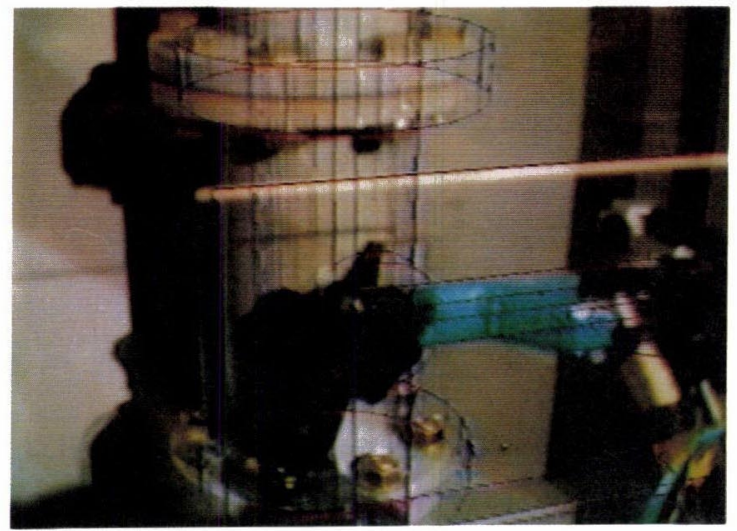

Fig. 11 Operation in visible environment

が，レバーの握り手（基準座標系の $x$ 軸方向 $6[\mathrm{~cm}], y$ 軸方向 $10[\mathrm{~cm}], z$ 軸方向 $3[\mathrm{~cm}]$ の大きさである.) の中心に一致するよ うにハンドを動かす。この場合，実環境において，ハンドの接 触部の中心とレバーの握り手の中心の位置誤差が， $x$ 軸方向 $8[\mathrm{~cm}]$ 以内かつ $y$ 軸方向 $6[\mathrm{~cm}]$ 以内であれば, ハンドはレバ 一に接触する. 前述のキャリブレーション精度の推定值が正し いとすれば，ハンドとレバーの中心位置の誤差は， $x$ 軸方向 $7[\mathrm{~cm}]$ 以内, $y$ 軸方向 $4 \mathrm{~cm}$ 以内と考えられ, 接触の条件を満 たしている.

接触の際，インピーダンス制御系は，接触力に応じてハンド 位置を変化させ, 安定に回転動作を行う. Fig. 11 に示すよう に，キャリブレーション後も仮想環境と実環境にずれが残って いるが, この程度のずれは，ハンドがレバーに接触しさえすれ ば，インピーダンス制御により補償可能である.

Fig. 12 に, 不可視環境下での作業実験時の, ディスプレイ 画像を示す.Fig. 12 ( a ) は煙による不可視環境下での実際 のカメラ画像に仮想環境のワイヤフレームモデルを重ねて描い たものである、実験環境のスモークマシンによる煙によって， 実験環境もロボットハンドもほとんど見えない状態になる. (b) は不可視環境下での作業時に，オペレータが見ている仮想 環境の画像である.（c）に作業を終えて, 煙を排出したときの 結果を示す。レバーの回転作業に成功していることが分かる.

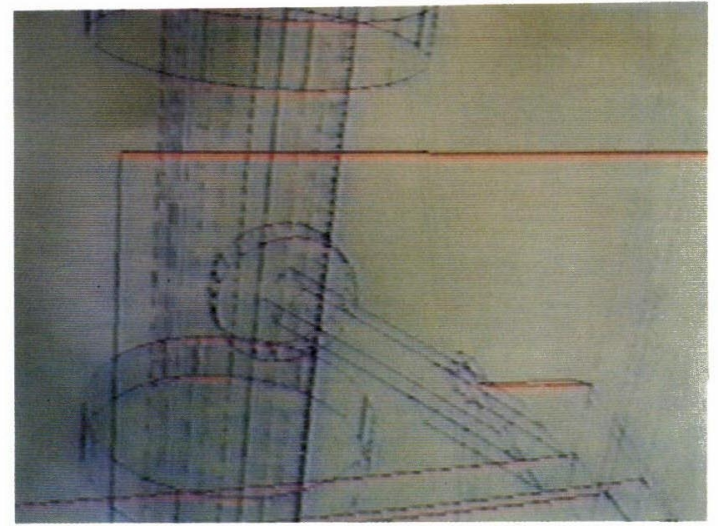

(a) Real image and virtual image in almost invisible environment

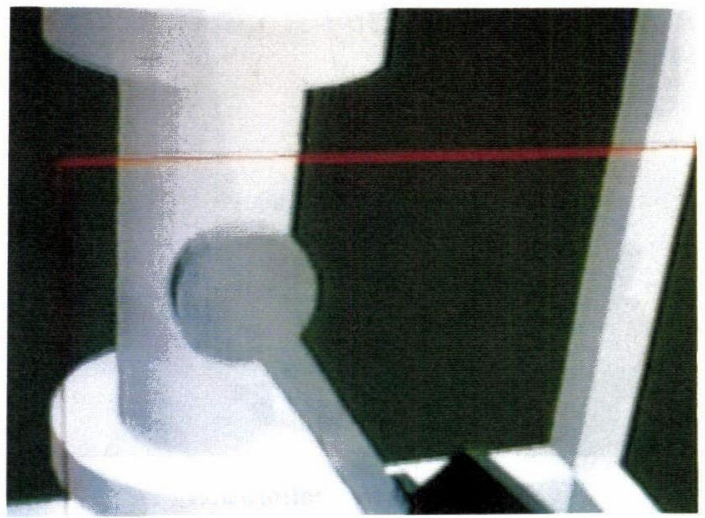

(b) Virtual image

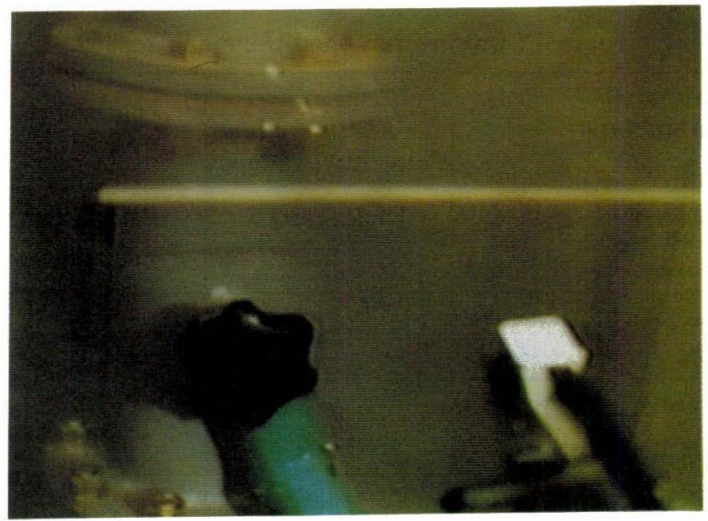

(c) Result

Fig. 12 Display images of operation in almost invisible environment

\section{6. おわりに}

画像計測によりパラメー夕誤差を推定することにより，実環 境と仮想環境との重ね合わせを行った。重ね合わせが実現され ていることを確かめるために, 不可視環境下での作業を行い, 検証実験に成功した.

現時点では, 実画像と仮想環境画像との対応付けは人間が行 っているため, キャリブレーションに, 非常に時間がかかる. 
より精度の高い重ね合わせを実現するためには推定すべき変数 を増やすことが必要であり，必要な観測回数はさらに増大す る. 現在, マーカーの利用による対応付けの自動化を検討中で あり，また，既知情報を基に，画像認識を行って，自動的に対 応付けを行うことも検討している.

火災が起こった場合等, 形状そのものが，完全に変わってし まい, 環境モデルのパラメータを修正するだけでは, 十分な近 似を行うことができない可能性もある．3 次元の環境モデルの 形状データを得るためには, 距離センサが必要である. パラメ ータでは表現できないモデル化誤差や，破壊による物体形状の 構造的変化等の距離センサによる修正は今後の課題である.

\section{謝辞}

本研究において，数多くの助言を下さった工業技術院機械技 術研究所ロボット工学部感覚制御課課長小森谷清殿に深謝致し ます。

\section{参 考 文 献}

[1] 舘, 谷江, 小森谷： “感覚情報呈示機能をもったマニピュレータの操 縦方式”, 特許 1348263 号, 出願 1981 年 1 月 14 日.

[2] 舘, 阿部 : “テレイグジスタンスの研究第 1 報”, 第 21 回 SICE 学 術講演会予稿集, pp. 167-168, 1982.

[ 3 ] 舘, 荒井：“テレイグジスタンスにおける視賞情報提示系の設計と評
価”, 日本ロボット学会誌, vol. 7, no. 4, pp. 314-326, 1989.

[ 4 ] S. S. Fisher et al.: "Virtual environment display systems," ACM 1986 Workshop on Interactive 3 D Graphics, pp. 1-11, 1986.

[5] S. Tachi, H.Arai and T.Maeda: "Tele-existence simulator with artificial reality," Proceedings of IEEE International Workshop on Intelligent Robotics and System (IROS' 88), pp. 719-724, 1988.

[6] 舘：“テレロボティクスとテレイグジスタンス”,計測と制御, vol. 28, no. 12, pp. 1059-1064, 1989.

[7] S. Tachi, H. Arai and T. Maeda: "Development of anthropomorphic tele-existence slave robot," Proceedings of International Conference on Advanced Mechatronics, pp. 385-390, 1989.

[8] S. Tachi, H. Arai and T. Maeda: "Tele-existence master slave system for remote manipulation," IEEE International Workshop on Intelligent Robotics and Systems (IROS' 90), pp. 343-348, 1990.

[9] 常本,舘他：“テレイグジスタンスの研究 第 25 報 一作業用仮想環 境の構築—”, 日本ロボット学会第 8 回学術講演会予稿集, no.2, pp. 565-566, 1990.

[10］大山,舘他：“テレイグジスタンスの研究 第 26 報 一仮想環境と実 環境の整合—”, 日本ロポット学会第 8 回学術講演会予稿集, no. 2, pp. 567-568, 1990.

[11] 大山,舘：“モデルベースト画像計測システム”, 機械学会論文集 (C), vol. 56, no. 521, pp. 109-115, 1990.

[12] 井上,舘：“マスタースレーブ・マニピュレータのインピーダンス制 御の一手法”, 日本ロボット学会誌, vol. 10, no. 4, pp. 490-500, 1992.

[13] D. W. Marqurdt: An algorithm for least square estimation of nonlinear parameters", Journal of Society of Industrial Applied Mathematics, vol. 11, 1963.

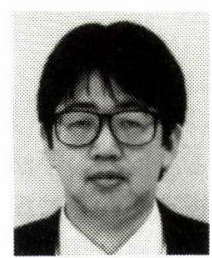

大山英明 (Eimei Oyama)

1962 年 10 月 23 日生. 1987 年 3 月東京大学大学 院工学系研究科修士課程修了. 同年 4 月通産省工 業技術院機械技術研究所入所. ロボット工学部バ イオロボティクス課所属. テレイグジスタンス, 人 間の運動制御のモデル化, 神経回路, 非線形最適化 等の研究に従事. 電子情報通信学会, 計測自動制御 学会, 日本ロボット学会等の会員.

(日本ロボット学会正会員)

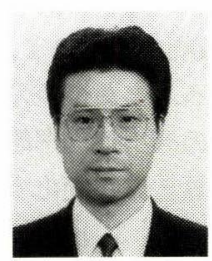

舘 暲 (Susumu Tachi)

1946 年 1 月 1 日. 1973 年東京大学大学院工学系研 究科博士課程修了, 工学博士, 東京大学助手. 1975 年通産省工業技術院機械技術研究所入所, バ イオロボティクス課長. 1979 年より 1980 年, マ サチューセッツ工科大学客員研究員. 1989 年, 東 京大学助教授. 1992 年, 東京大学教授. 国際計測 連合学会 (IMEKO) ロボティクス会議議長.

（日本ロボット学会正会員）

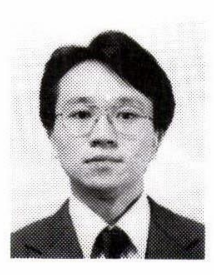

常本 直貴 (Naoki TSUNEMOTO)

1960 年 11 月 21 生. 1988 年 3 月東京大学大学院 理学系研究科修士課程修了. 同年 4 月通産省工業 技術院機械技術研究所入所. 物理情報部バイオメ カニクス課所属. ヒューマン・インターフェースの 研究に従事. 高分子学会, 日本生物物理学会等の 会員.

(日本ロボット学会正会員)

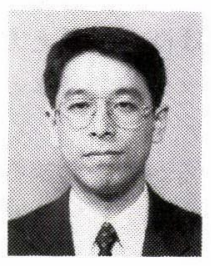

井上康之（Yasuyuki Inoue）

1958 年 4 月 27 日生. 1982 年早稲田大学理工学部 電気工学科卒業. 同年(株)安川電機入社. 1989 年 加ら 90 年通産省工業技術院機械技術研究所研修 員. 現在安川電機つくば研究所在籍, 電動機制 御, マニピュレー夕制御などの研究に従事. 電気 学.

（日本ロボット学会正会員） 